\title{
BIOSORPTION OF MERCURY FROM WASTEWATER USING ISOLATED ASPERGILLUS Sp. MODIFIED 1,10-PHENANTHROLINE: HILL ISOTHERM MODEL
}

\author{
Shameran J. Salih a,*, Sewgil S. Anwer ${ }^{\text {b }}$, Rezhna H. Faraj ${ }^{\text {a }}$ \\ ${ }^{a}$ Dept. of Chemistry, Faculty of Science and Health, Koya University, Koya, Kurdistan Region, Iraq - (shameran.jamal, \\ rezhna.hassan)@koyauniversity.org \\ ${ }^{\mathrm{b}}$ Dept. of Clinical Biochemistry, College of Health Science, Hawler Medical University, Erbil, Kurdistan Region, Iraq - \\ (dr.sewgil75@gmail.com)
}

Received: Jul. 2017 / Accepted: Dec., 2017 / Published: Dec., 2017

https://doi.org/10.25271/2017.5.4.379

\begin{abstract}
:
Equilibrium biosorption of mercury (II) onto new developed biosorbent (1,10-phenanthroline-graft- cell/Filamentous fungi) in both free, immobilized and dead cell were investigated. The product was characterized by Fourier transform infrared spectroscopy (FTIR) and scanning electron microscopy (SEM). In this work several isotherm models applied to predict the process design for the adsorption system. Hill, Sips, Langmuir and Freundlich utilized to determine the adsorption parameters, the equilibrium data fitted well to Hill and Sips isotherm models followed by Langmuir. Meanwhile, the maximum adsorption capacity proposed by Hill model was 78.67(mg/g) and Sips 78.42(mg/g) were lower than Langmuir models which was 85.16(mg/g). In other hand, the equilibrium data almost fitted to the Freundlich isotherm supporting the postulation of the heterogeneous shape of biosorption to certain range. Hence, On the bases of Langmuir model the biosorption of $\mathrm{Hg} 2+$ onto 1,10-phenanthroline-graft- cell/Filamentous was in the favourable area and that confirmed by calculating the separation factor (RL<1). Nevertheless, new isotherm (Eq. 4) has been derived by the combination of a Langmuir and Freundlich models. The new model agreed well enough $(\mathrm{R} 2=0.9863)$ with the experimental data.
\end{abstract}

KEYWORDS: Hill and Sips isotherm, Biosorption, Modified-Aspergillus Sp. Wastewater.

\section{INTRODUCTION}

Heavy metal ions are non-degradable and highly toxic even at low concentration. Environmental mercury levels have increased considerably in recent years. The direct anthropogenic sources of mercury in water bodies are related to numerous industrial applications (e.g., chloroalkali productions, pharmaceutical and cosmetic preparations, electrical instruments, and pulp and paper industries) and many products of common use (e.g., thermometers, batteries, and medical drugs) (Pavlish et al., 2004). Hg (II) is the poisonous metal ions that cause both acute and chronic toxicity to the central nervous system, kidneys, lung tissues, and reproductive system (Adams et al. 2005). Removal of heavy metal using living or dead organisms has received more attention in recent years because of their potential application in environmental protection.

The expression of biosorption is utilized to characterize the passive non- metabolically mediated process of heavy metal linkage to living or dead biomass (Rangsayator et al., 2002). Biosorption of $\mathrm{Hg}$ (II) from aqueous solutions can be examining as an alternative technology in treatment of industrial wastewater. The technique is emerging technologies depend on the power of biological materials to uptake heavy metals from wastewater by either physicochemical or metabolically mediated pathways of removal process (Brinza et al., 2007).

A set of inexpensive biomass has been investigated and manufactured for removal of pollutant from aquatic systemin various parts worldwide (Kar \& Misra, 2004). They include algae (Elifantz \& Tel-Or, 2002), fungi (Conesa et al., 2005), anaerobically digested sludge(Tokcaer \& Yetis, 2006)and bacteria (Liu et al., 2006). Waste materials have also been.
These include groundnut husk (Okieimen et al., 1985), rice bran, soybean and cottonseed hulls (Marshall et all, 1999), coir, jute and sawdust (Shukla \& Pai, 2005), crop milling waste (Aubert et al., 2005), canola meal and coconut shell (Ajayi et al., 2002)amongst others. Generally, microorganisms are used closely in diverse food-pharmaceutical industries, they are created as waste, which can be achieved free or at low-cost from these industries. Nevertheless, they show high capabilities in adsorption of organic and inorganic toxicity from aqueous solutions. This is due to the presence of alginate, which is present in gel form in their cell walls. Also, their macroscopic structure proposed a proper basis for the produce of bio sorbent particles that are convenient for adsorption process applications. Lately, many approaches have been made for the evaluation of low cost adsorbents from agriculture wastes and industries.

Meanwhile, it is principally the cell wall of certain bacteria, fungi and algae which is found to be responsible for the process of biosorption. The cell wall of cyanobacteria involves hydroxyl, carbonyl, carboxyl, sulphahydryl, sulphonate, amine, imine, imidazole, phosphor diester groups and thioether (Venkatesh et al., 2003).

Here, Filamentous fungi (Aspergillus, Penicillium, Rhizopus and Mucor) may be utilized in boisorption process (Gaad, 1990). The cell wall of the fungi is the first to come into contact with metal ions in solution, due to high electron exchange capacity of their cell walls. These features arise from large density of functional groups in the cell wall that create a negative charged surface (Ledin et al, 1996).

Finally, the objective of this study is to design a new composite biosorbent by introducing 1,10-phenethroline into a cell/Filamentous fungi, as an alternative modified adsorbent for the removal of $\mathrm{Hg}$ (II) ions from aqueous solutions. In this work, different parameters have been investigated such as effect of

\footnotetext{
* Corresponding author

This is an open access under a CC BY-NC-SA 4.0 license (https://creativecommons.org/licenses/by-nc-sa/4.0/)
} 
initial $\mathrm{Hg}$ (II) solution, contact time, concentration on adsorption, $\mathrm{pH}$ and temperature was evaluated and compared with 1,10-phenanthroline-graft- cell/Filamentous fungibinding $\mathrm{Hg}$.

\section{MATERIALS AND METHODS}

\subsection{Materials}

All reagents were for analytical grade and used without further purification, Mercury Chloride (Sigma -Aldrich), 1,10-phenanthroline (Analar), hydrochloric acid 37\% (Merck), sodium hydroxide(Sigma-Aldrich), potassium chloride (Aldrich), potassium hydrogen phthalate (Merck),sodium hydrogen carbonate (Sigma -Aldrich) and potassium hydrogen phosphate (Merck) were used to prepare the buffer solutions with different $\mathrm{pH}$ values.

\subsection{Instruments}

Instruments that have been used in this work are listed in the Table 1.

Table 1. Instruments used in this work

\begin{tabular}{lcl}
\hline \multicolumn{1}{c}{ Instruments } & Made & \multicolumn{1}{c}{ Function } \\
\hline $\begin{array}{l}\text { Spectrophotometer } \\
\text { (UV/Vis) }\end{array}$ & $\begin{array}{c}\text { Aglient } \\
\text { Technology Cary } \\
\text { UV-Vis } \\
\text { spectrophotometer }\end{array}$ & Absorbance \\
NORAN & $\begin{array}{l}\text { Images providing } \\
\text { compositional, } \\
\text { Microscopy (SEM }\end{array}$ & $\begin{array}{l}\text { morphological and } \\
\text { topographical }\end{array}$ \\
& information \\
Sensitive weight & HTCE 3000g & To measure weight \\
balance & $0.01 g$ & To shake the \\
Incubator shaker & GFL 3031 & samples \\
Oven & De dry samples \\
PH meter & Pro & phamber \\
FT-IR & SHIMADZU & $\begin{array}{l}\text { Measurement of } \\
\text { pH } \\
\text { To obtain } \\
\text { spectrum of } \\
\text { absorption }\end{array}$ \\
\hline
\end{tabular}

\subsection{Preparation of Biosorbent}

Sample Collection and Fungus Isolation: Soil samples were collected from area near to waste products. The soil samples were transported to the laboratory for fungal isolation. Different dilutions such as 10-3 -10-6 were prepared from this stock solution in sterile distilled water under aseptic conditions. $0.1 \mathrm{ml}$ of diluted suspension placed on PDA plates contain $25 \mathrm{mg}$ Chloramphenicol to inhibit bacterial growth. Plates were incubated at $25^{\circ} \mathrm{C}$ for 5-7 days. After sub culturing on PDA pure culture obtained and fungal colonies were identified according to morphological and microscopic characteristics (Nagamani et al., 2006).

\subsection{Composite Matrix}

First, $8 \%$ (w/v) of fungal colonies were mixed with fresh $10 \%$ $(w / v)$ of 1,10-siphenanthroline then agitated overnight in a controlled temperature $(30 \mathrm{oC})$ and shaking $180 \mathrm{rpm}$ in an incubator shaker. The sample was filtrate washed by deionized water $/ 3$ times then oven-dried at $50{ }^{\circ} \mathrm{C}$ for $10 \mathrm{hrs}$. Finally, the obtained biomass (1,10-phenanthroline-graftcell/Filamentous fungi) kept in a dissector for moisture avoided. In addition, all instruments that used for this work are summarized in Table 1.

\subsection{Batch Equilibrium Studies}

The adsorption of Mercury and removal efficiency by the composite matrix was investigated using the batch equilibrium method. A solution of $40 \mathrm{mg} . \mathrm{L}^{-1}$ of $\mathrm{Hg}^{2+}$ was prepared by dissolving $0.0541 \mathrm{~g}$ of mercury chloride in $1000 \mathrm{ml}$ of deionized water then a $50 \mathrm{ml}$ of $\mathrm{Hg}^{2+}$ solution was prepared and equilibrated using a magnetic stirrer. Different amount of biosorbent have been tested $(20,40,60,80$ and $100 \mathrm{mg})$ was then suspended in the $\mathrm{Hg}^{2+}$ solution and shaken until equilibrium time is reached. After filtration, the amount of adsorbed $\mathrm{Hg}^{2+}$ ions was calculated from the variation between the initial and final concentration (Non-adsorbed molecules) of $\mathrm{Hg}^{2+}$ ions, measured by UV-visible spectrophotometer at a wavelength of $575 \mathrm{~nm}$. (Rashid et al., 2016). Furthermore, in order to study the effect of temperature on the adsorption process the batch performed at different temperatures, also various solution $\mathrm{pH}$ have been conducted( $\mathrm{pH}=3,7$, and 10). The removal of mercury per unit mass of biosorbent was then calculated through mass-balance calculations (Gladstone, et al., 2015):

$$
q_{e}=\frac{C_{o}-C_{e}}{W} \times V
$$

where $\quad q_{e}=$ Amount of adsorbed $\mathrm{Hg}^{2+}(\mathrm{mg} / \mathrm{g})$

$C_{o}=$ Initial concentration $\left(\mathrm{mgl}^{-1}\right)$

$C_{e}=$ Equilibrium concentration $\left(\mathrm{mgl}^{-1}\right)$

$W=$ Mass of adsorbent $(\mathrm{mg})$

$V=$ Solution volume $(\mathrm{ml})$

The removal percentage was determined using the equation below (Salih, 2014):

$$
R \%=\frac{C_{o}-C_{e}}{C_{o}} \times 100
$$

where $\quad C_{o}$ and $\mathrm{C}_{\mathrm{e}}=$ Initial and final $\mathrm{Hg}^{2+}$ concentration $\left(\mathrm{mgl}^{-1}\right)$ $R \%=$ Removal percentage

Also, scanning electron microscopy (SEM) was used to identify the surface morphology of the prepared adsorbent (model HTCE $3000 \mathrm{~g} 0.01 \mathrm{~g}$ ) which was dried for $24 \mathrm{hrs}$ at $105^{\circ} \mathrm{C}$ before SEM loaded.

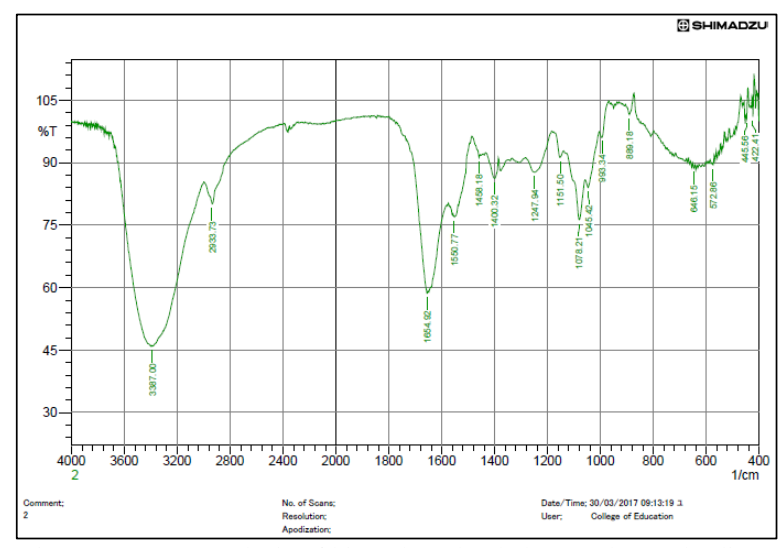

Figure 1. FT-IR analysis of biosorbent loaded 1,10-phenanthrolinegraft- cell/Filamentous fungi. 


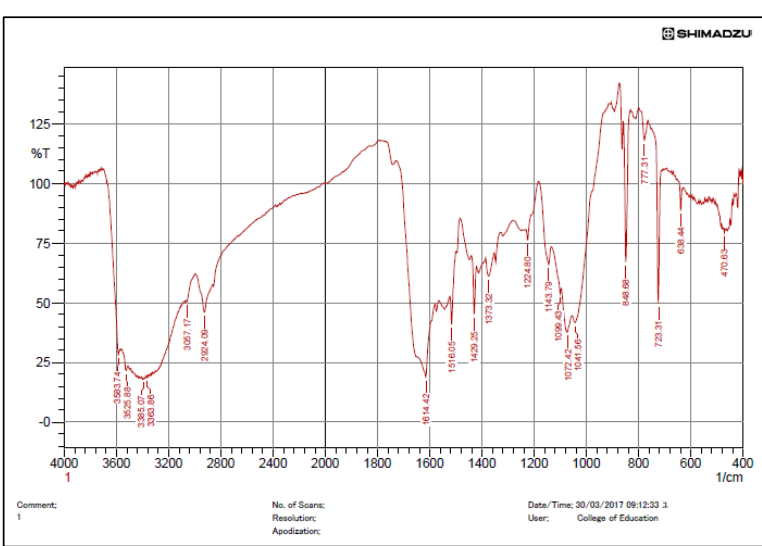

Figure 2. FT-IR analysis of biosorbent loaded 1,10-phenanthrolinegraft- cell/Filamentous fungi-binding $\mathrm{Hg}$.

\section{RESULTS AND DISCUSSTION}

\subsection{FT-IR Characterization}

The important Infrared spectra of the complex (1,10phenanthroline-graft- cell/Filamentous fungi-binding $\mathrm{Hg}$ ) is compared with the Infrared of the ligand (1,10phenanthroline-graft- cell/Filamentous fungi) for determining the changes happened, significant picks from Figure 1 and Figure 2 are listed in the Table 2. The absorption stretching band of $\mathrm{C}=\mathrm{O}$, and $\mathrm{C}=\mathrm{N}$ aromatic ring appeared at $1654 \mathrm{~cm}-1$ and $1550 \mathrm{~cm}-1$ in the ligand is shifted toward slower wave number in the complex that appear at $1614 \mathrm{~cm}$ 1 and $1516 \mathrm{~cm}-1$ respectively, which indicates coordination via $\mathrm{C}=\mathrm{O}$ of the fungi and the nitrogen atoms from the 1,10 phenanthroline. This is also confirmed by the appearance of a new band at $470 \mathrm{~cm}-1$ in the complex which assigned to the Hg-N bond (Ranjbar et al., 2013).

\begin{tabular}{lccccc}
\multicolumn{6}{c}{ Table 2. Selected IR Spectral of ligand and complex (cm-1) } \\
\hline & $\mathrm{O}-\mathrm{H}$ & $\mathrm{C}=\mathrm{N}$ & $\mathrm{C}=\mathrm{O}$ & $\begin{array}{l}(\mathrm{C}-\mathrm{H}) \\
\text { group }\end{array}$ & $\mathrm{Hg}-\mathrm{N}$ \\
\hline $\begin{array}{l}\text { Ligand } \\
\begin{array}{l}1,10 \text { phenanthr } \\
\text { oline) }\end{array}\end{array}$ & 3387 & 1550 & 1654 & 2933 & --- \\
$\begin{array}{l}\text { (Hg_ Ligand) } \\
\text { complex }\end{array}$ & 3385 & 1516 & 1614 & 2924 & 470 \\
\hline
\end{tabular}

\subsection{Microscopically Study}

Microscopically examination from soil isolates showed that Conidiophores and septate, unbranched hyphae, with a swollen apex (vesicle), conidia in dry chains forming compact columns (columnar) that can be identified as Aspergillus Sp. As shown in Figure 3. The same study observed by (Gladstone, et al., 2015).

\subsection{Scanning Electron Microscopy (SEM) Analysis}

The morphology of the biosorbent, 1,10-phenanthroline and composite matrix which is 1,10-phenanthroline-graftcell/Filamentous fungi-binding- $\mathrm{Hg}$ have been examined using SEM with magnification of 10000 to indicate the porous sites of cell/Filamentous fungi as shown in Figure 4A, further Figure 4-B and 4-C elucidate the successful loaded of 1,10-phenanthroline and binding with $\mathrm{Hg}^{2+}$ respectively. Meanwhile, the composite matrix demonstrated some microcracks in the surface (Zhang et al., 2012). Nevertheless, the particles are mostly irregular in shape and circular within indication of a rougher surface in the composites with a higher content of 1,10-phenanthroline, this characteristic change in the analyzed SEM images emphasize the presence of 1,10phenanthroline and mercury in the surface of cell/Filamentous fungi.

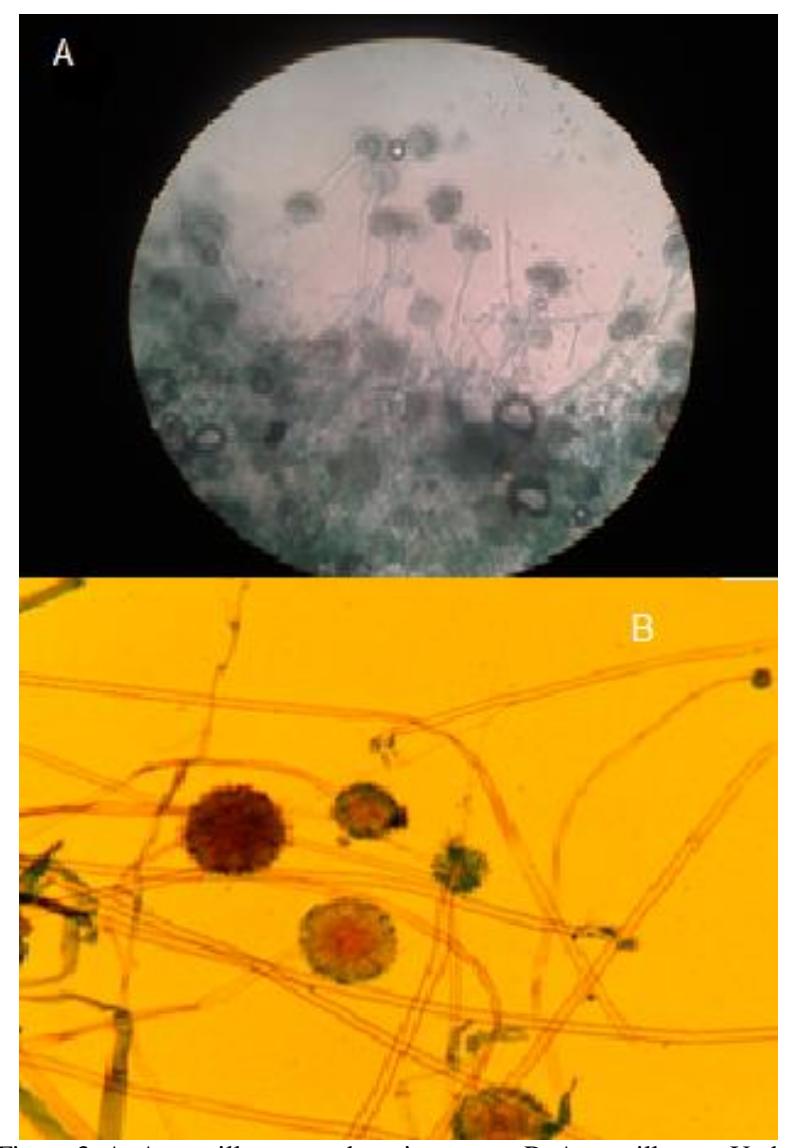

Figure 3. A. Aspergillus sp. under microscope, B. Aspergillus sp. Under microscope stained with lactophenol

\subsection{Biosorption Mechanisms}

The microorganism associates with heavy metals by a composite of different metal binding mechanisms involved physisorption, ion-exchange and complexation (Venkatesh et al., 2003). Nevertheless, the physisorption as explained from previous studies (Ahalya et al., 2003) which includes the electrostatic interaction (Van der-waals forces) occur between the cell wall of microbes and metal ion in the solution. However, these interactions are responsible in mercury biosorption utilize Aspergillus $\mathrm{Sp}$. Furthermore, the biosorptive process as described by complexation mechanisms occurs onto biosorbent via formation of coordinate bonds between the reactive groups on the surface of cell wall and the metal ion. Moreover, Similar results are confirmed elsewhere (Gladstone et al., 2015). Here, attempts were made to evaluate different type of the Aspergilus $\mathrm{Sp}$. involves free cell, immobilized and dead cell in removal process, as the Figure 5 indicate that the dead cell of the biosorbent showed high ability for mercury uptake in adsorptive study. 

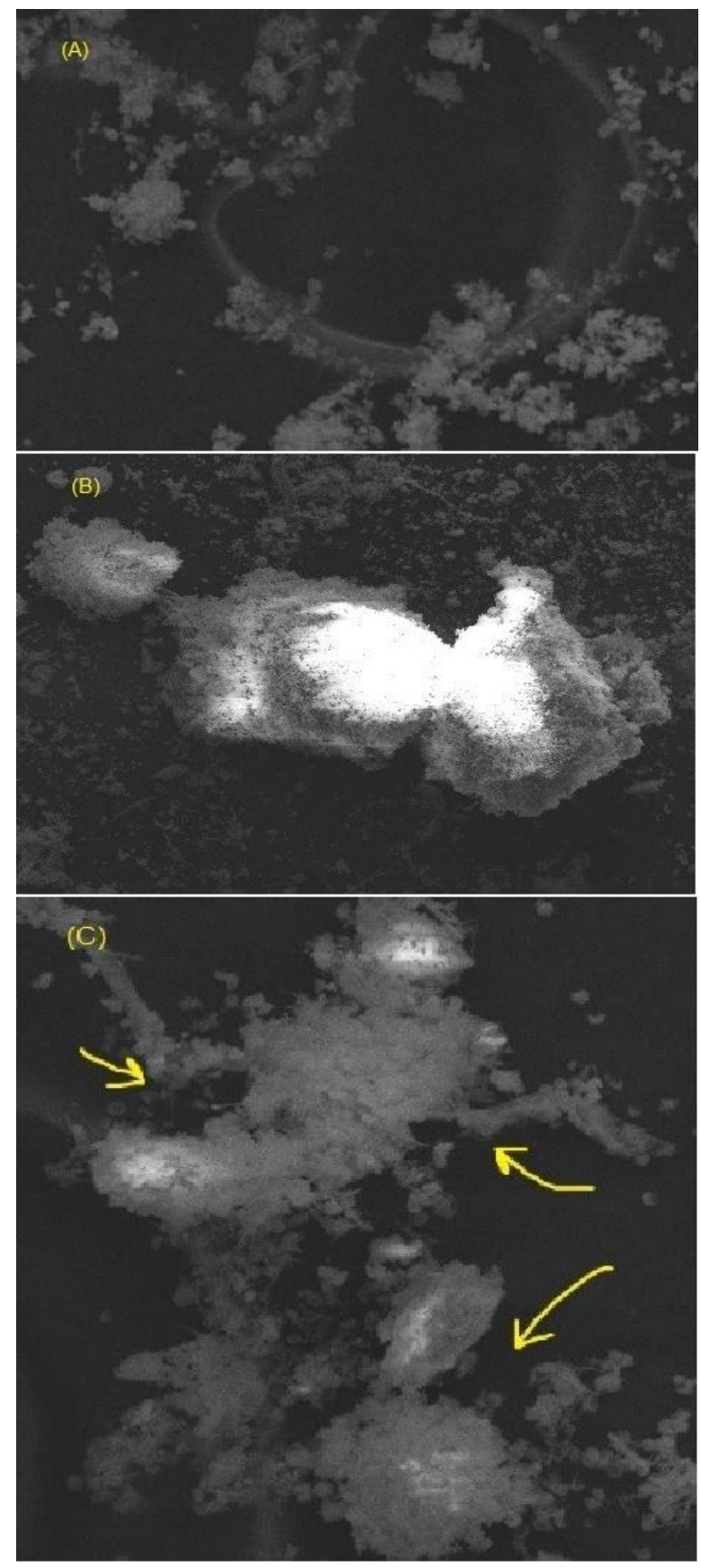

Figure 4. (A, B and C): SEM images cell/Filamentous fungi, 1,10phenanothroline loaded and modified biosorbent binding $\mathrm{Hg} 2+$ respectively

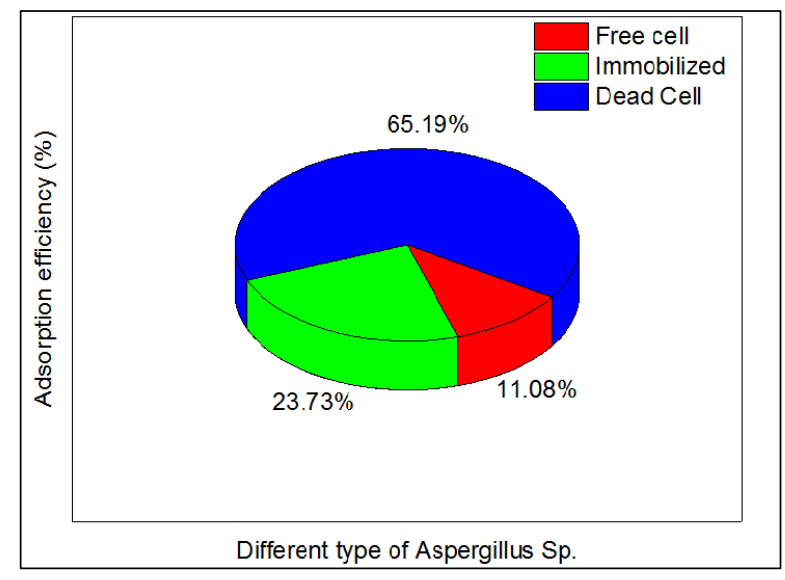

Figure 5. Different type of Aspergillus Sp. Loaded in removal process
3.5 Study of parameters that have effect on the adsorption process

3.5.1 Effect of Initial Biosorbent Dosage: The effect of biosorbent on the adsorption of $\mathrm{Hg} 2+$ are showed in Figure 6, it is easily understood that the biosorption efficiency increased with increasing the amount of biosorbent until reached maximum uptake of $89 \% \mathrm{Hg} 2+$ at a certain limit $500 \mathrm{mg}$ of the biosorbent. At the first stage, rapid increase of biosorption of mercury (II) with the increase in the amount of 1,10-phenanthroline-graftcell/Filamentous fungi perhaps attributed to high availability of binding sites (Salih, 2014). However, all the available sites have been covered by the metal-complex, but after this critical dosage $(500 \mathrm{mg})$ of the biosorbent the number of binding sites increases with slower of biosorption rate, since all the active sites may not obtainable due to overlapping between sorbent sites themselves and/or shortage of the concentration of $\mathrm{Hg} 2+$ in the solution (Nowicki et al., 2013).

3.5.2 Effect of $\mathrm{pH}$ on biosorption of mercury onto AspergillusSp: In a biosorption process it is quite important to evaluate the effect of $\mathrm{pH}$ in order to maintain the amount of adsorption capacity. Biological evolution also based on the $\mathrm{pH}$ of the aqueous media (Zhang et al., 2012). In this work, three different $\mathrm{pH}$ solution have been examined $(\mathrm{pH} 10=3,7$ and 10), this procedure perhaps elucidate by the study of $\mathrm{pH}$ point zero charge (pHpzc)which describe the net 11 surface charge of the biosorbent when equal to zero. In other word, drift method used to determine the $\mathrm{pH}$ point zero charge $(\mathrm{pHpzc}=6)$. Figure $7(\mathrm{~A}$ and $\mathrm{B})$ demonstrate that higher adsorption capacity $(\mathrm{mg} / \mathrm{g})$ and higher adsorption efficiency (\%R) occurred at $\mathrm{pH}=3$ in comparison to $\mathrm{pH}=7$ and 10 . This may due to, that the solid surface adsorbed positive charge from the acidic solution while the $\mathrm{pH}$ equal 3 the predominate form in the solution are $\mathrm{HgCl} 2$ and $\mathrm{HgCl} 3$ - (Patil \& Shrivastava, 2010)followed by electrostatic interactions between the solid surface and the negative forms of complexes metal intend to increase the biosorptive process. As confirmed by figure 7(A and $\mathrm{B}$ ) when the $\mathrm{pH}$ of the solution increased $(\mathrm{pH}=7)$ the adsorption capacity and adsorption efficiency decreased because there is not a significant interactions between adsorbate and the adsorbent. In this case the net charge is closed to $\mathrm{pHpzc}$ (net surface charge $=$ zero). Finally, when the solution achieved at $\mathrm{pH}$ equal 10 the biosorption rapidly diminished for the reason that electrostatic repulsion are dominant between negative charged of the solid surface and the metal ion and this biosorption more difficult. Similar studies reported elsewhere (Chakraborty et al., 2011).

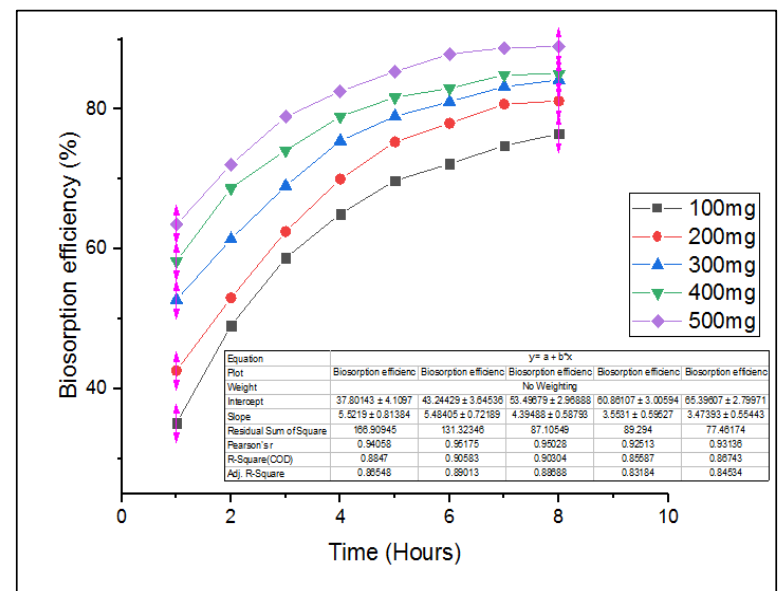

Figure 6. Effect of biosorbent dose on removal of $\mathrm{Hg} 2+$ onto Aspergillus Sp. initial $\mathrm{Hg} 2+$ concentration 50mg/L, temp 298K, shaking speed $180 \mathrm{rpm}$. 


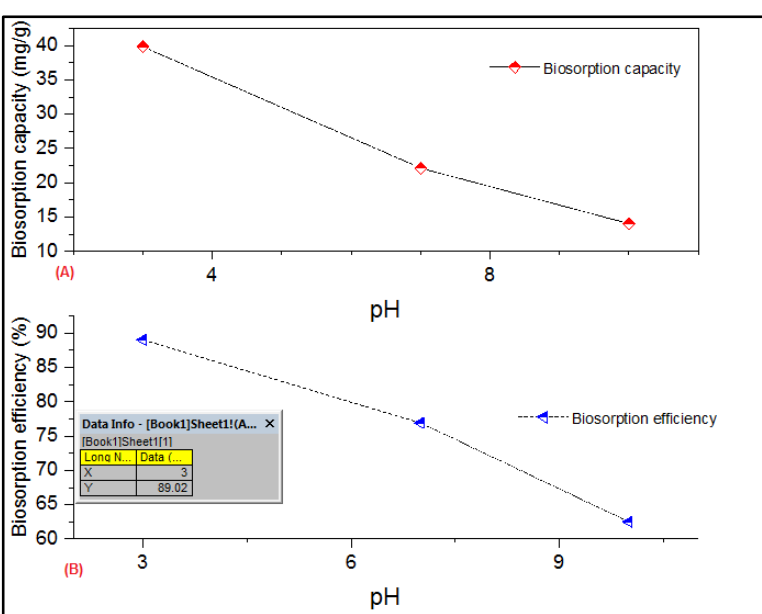

Figure 7. A- biosorption capacity of mercury onto Aspergillus Sp. in different $\mathrm{pH}$ solution, $\mathrm{B}$ - biosorption efficiency of mercury onto Aspergillus Sp. in different solution $\mathrm{pH}$

3.5.3 Effect of temperature on biosorption of mercury onto Aspergillus Sp.: The biosorption of mercury onto Aspergillus Sp. was studies at different temperatures of 25, 35,45 and $60{ }^{\circ} \mathrm{C}$. In the spite of the fact that heat plays a major role in biosorption process based on the stability of cross-linked of microorganism-metal complex (Salih \& Rashid, 2015). Figure 8 showed that the biosorption efficiency inversely change with increasing temperature as confirmed from obtained data. However, the metal uptake decreased from $71.44 \%$ to $47.92 \%$ at $298 \mathrm{~K}$ to $333 \mathrm{~K}$ respectively. This refers to the weakening interaction of sorbent sites and the metal ion which was explained by Vander Waals interaction that occurred between the modified Aspergillus Sp. and $\mathrm{Hg}^{2+}$. Meanwhile, the loading capacity decrease with rise of temperature. In other word, the rate of desorption is more noticeable than the rate of biosorption and it is quit evidence that the biosorption of mercury onto 1,10 phenanthroline-graft- cell/Filamentous fungi is an exothermic process (Nowicki et al., 2013). Finally, the obtained results propose that a high temperature is not preferable for biosorption of $18 \mathrm{Hg} 2+$ when the 1,10 phenanthroline-graft- cell/Filamentous fungi is biosorbent.

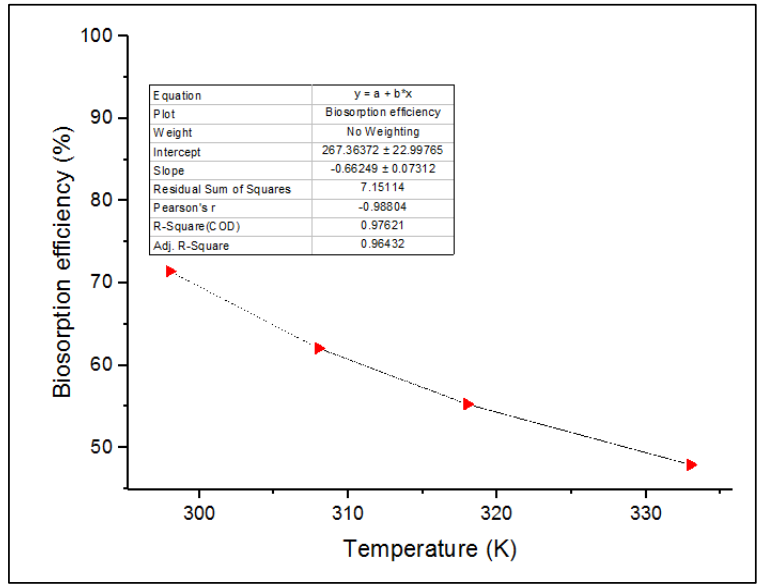

Figure 8. Effect of temperature on the biosorption of mercury onto 1,10-phenanthroline-graft- cell/Filamentous fungi.

\subsection{Biosorption Isotherm}

Newest isotherm (Hill isotherm) have been evaluated and compared with two common isotherms (Langmuir and Freundlich) to describe the metal ion $\left(\mathrm{Hg}^{2+}\right)$ binding to the surface of biosorbent. Table 3 represents the isotherm models, nonlinear form, linear form and the plot equations.

3.6.1 Hill isotherm model: The Hill isotherm model suggested adsorption isotherm to designate various adsorbate binding and non-ideal cooperative phenomenon with the ligand binding capability at one site onto macromolecular, influencing different binding sites on the same macromolecular (Foo \& Hameed, 2010). The mathematical expression in the Equation (3):

$$
q_{e}=\frac{q H C_{e}^{n H}}{K_{D}+C_{e}^{n H}}
$$

where

$$
\begin{aligned}
& q_{e}: \text { Milligrams of } \mathrm{Hg}^{2+} / \text { gram of biosorbent } \\
& C_{e}: \text { Concentration of } \mathrm{Hg}^{2+} \text { at equilibrium }\left(\mathrm{g} . \mathrm{L}^{-1}\right) \\
& \mathrm{K}_{\mathrm{D}}, \mathrm{n}_{\mathrm{H}} \text { and } \mathrm{qH} \text { are } \mathrm{Hill} \text { isotherm constants }
\end{aligned}
$$

3.6.2 Langmuir isotherm model: This isotherm model gives a map of homogeneous surface within monolayer bonding and/or of the same strength between adsorbate molecules and the adsorbent (Oke et al., 2008). The mathematical expression is summarized in Table 3.

3.6.3 Freundlich isotherm model: The Freundlich isotherm model also applied in this work which describes the heterogeneous binding within multi-layer between adsorbate and the adsorbent (Oke et al., 2008). The mathematical expression is summarized in Table 3.

3.6.4 Sips isotherm model: The sips isotherm model assumed that the integration of both models (Freundlich and Langmuir) and postulating the heterogeneous surface for the adsorption framework. In addition, at high concentration of the solute it proposed of monolayer adsorption capacity and at low concentration of solute absolutely diminishes to multilayer adsorption capacity (Debnath \& Ghosh, 2008). The mathematical expression in the Equation (4):

$$
\frac{1}{q_{e}}=\frac{1}{Q_{\max } K_{s}}\left(\frac{1}{C_{e}}\right)^{\frac{1}{n}}+\frac{1}{Q_{\max }}
$$

where

$q_{e}$ : Milligrams of $\mathrm{Hg}^{2+} /$ gram of biosorbent $Q_{\max }$ : Maximum adsorption capacity $(\mathrm{mg} / \mathrm{g})$

$K_{s}$ and n: Sips isotherm constants

$C_{e}$ : Concentration of $\mathrm{Hg}^{2+}$ at equilibrium (g. $\mathrm{L}^{-1}$ )

As shown from Figure 9, the experimental results by observing the $\mathrm{R}^{2}$ values of the isotherm models, it was found that the Hill isotherm fitted well $\left(R^{2}=0.9896\right)$ and sips $\left(R^{2}=0.9863\right)$. However, the Langmuir model $\left(\mathrm{R}^{2}=\right.$ $0.9715)$ reasonably fitted the data followed by Freundlich model $\left(\mathrm{R}^{2}=0.9425\right)$. 


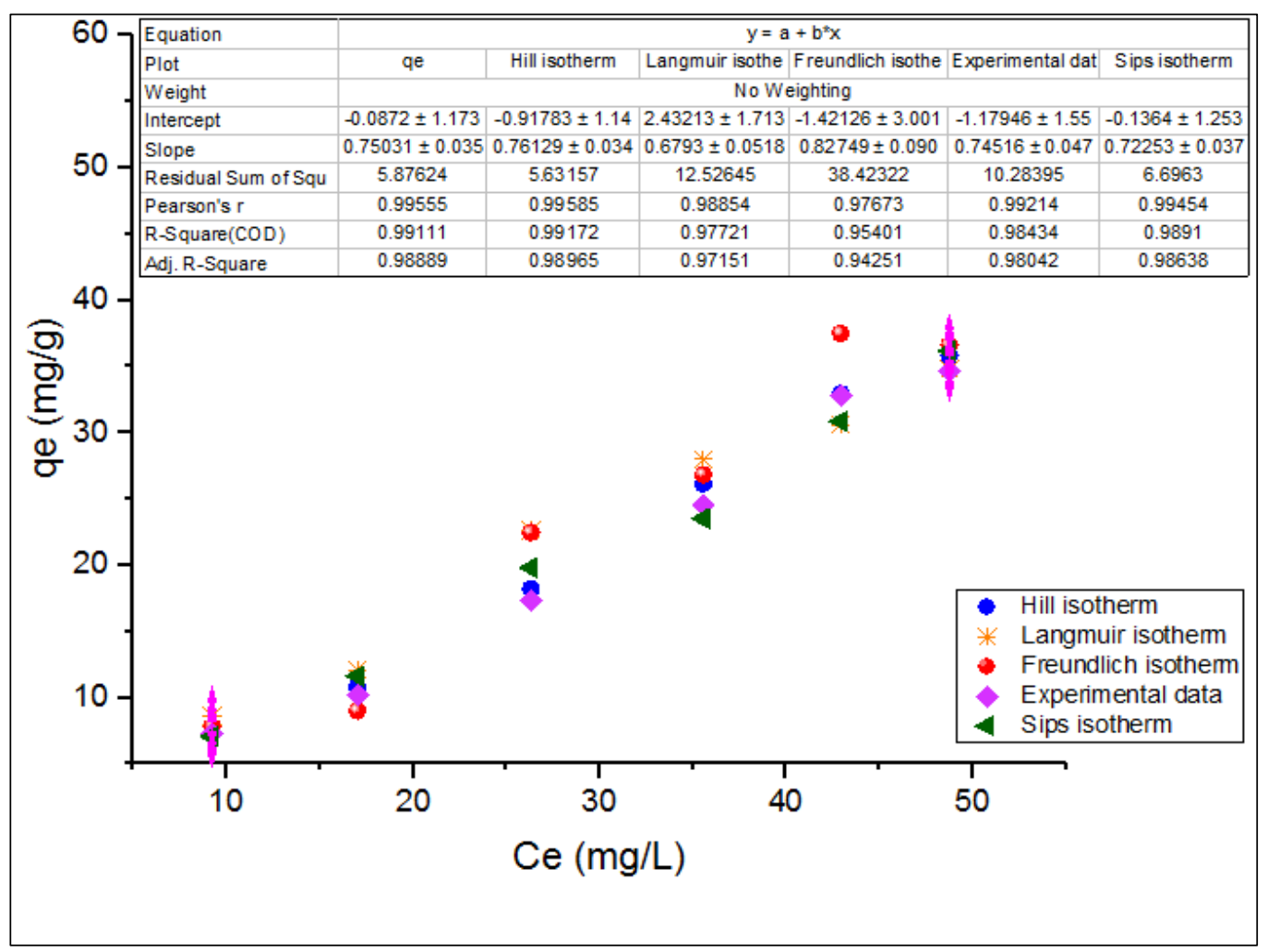

Figure 9. Isotherm models of Hill, Sips, Langmuir and Freundlich

The capacity of Hill and Sips models approved that the homogeneous biosorption on the heterogeneous surface of 1,10-phenanthroline-graft- cell/Filamentous and the cooperative phenomenon of the sorption $\mathrm{Hg}^{2+}$ ions. Furthermore, Hill isotherm was superior among the other isotherm models (Adie et al., 2010). The maximum adsorption capacity proposed by Hill model was $78.67(\mathrm{mg} / \mathrm{g})$ and Sips $78.42(\mathrm{mg} / \mathrm{g})$ were lower than Langmuir models which was $85.16(\mathrm{mg} / \mathrm{g})$. Table 4 showed the maximum adsorption capacity of applied isotherm models and their parameters. In other hand, the equilibrium data almost fitted to the Freundlich isotherm supporting the postulation of heterogeneous shape of biosorption to certain range. On the bases of Langmuir model the biosorption of $\mathrm{Hg}^{2+}$ onto 1,10phenanthroline-graft- cell/Filamentous was in the favourable area and that confirmed by the separation factor $(\mathrm{RL}<1)$ (Mittal et al., 2013).

Table 3. Isotherm models and their nonlinear and linear forms

\begin{tabular}{|c|c|c|c|}
\hline Isotherm & Linear form & Nonlinear form & Plot \\
\hline Hill & $\log \frac{q_{e}}{q_{H}-q_{e}}=n H \log \left(C_{e}\right)-\log K_{D}$ & $q_{e}=\frac{q H C_{e}^{n H}}{K_{D}+C_{e}^{n H}}$ & $\begin{array}{l}\log \frac{q_{e}}{q_{H}-q_{e}} \\
\left(C_{e}\right)\end{array}$ \\
\hline Langmuir & $\begin{array}{l}\frac{C_{e}}{q_{e}}=\frac{1}{b Q_{o}}+\frac{C_{e}}{Q_{o}} \\
\frac{1}{q_{e}}=\frac{1}{Q_{o}}+\frac{1}{b Q_{o} C_{e}} \\
q_{e}=Q_{o}-\frac{q_{e}}{b C_{e}} \\
\frac{q_{e}}{C_{e}}=b Q_{o}-b q_{e}\end{array}$ & $q_{e}=\frac{Q_{o} b C_{e}}{1+b C_{e}}$ & $\begin{array}{l}\frac{C_{e}}{q_{e}} v s C_{e} \\
\frac{1}{q_{e}} v s \frac{1}{C_{e}} \\
q_{e} v s \frac{q_{e}}{b C_{e}} \\
\frac{q_{e}}{C_{e}} v s q_{e}\end{array}$ \\
\hline Freundlich & $\log q_{e}=\log K_{F}+\frac{1}{n} \log C_{e}$ & $q_{e}=K_{F} C_{e}^{\frac{1}{n}}$ & $\log q_{e} v s \log C_{e}$ \\
\hline
\end{tabular}


Table 4. Statically results of isotherm parameters

\begin{tabular}{llc}
\hline \multicolumn{1}{c}{ Models } & \multicolumn{1}{c}{ Parameter } & $\mathrm{R} 2$ \\
\hline Hill & $\mathrm{q}_{\mathrm{e}}=78.67 \mathrm{mg} / \mathrm{g}$ & 0.9896 \\
& $\mathrm{~K}_{\mathrm{D}}=38.59$ \\
& $\mathrm{n}_{\mathrm{H}}=1.02$ & \\
& & \\
Spis & $\mathrm{qe}=78.42 \mathrm{mg} / \mathrm{g}$ & 0.9863 \\
& $\mathrm{n}=0.93$ & \\
& $\mathrm{Ks}=0.02$ & \\
Langmuir & $\mathrm{qe}=85.16 \mathrm{mg} / \mathrm{g}$ & 0.9715 \\
& $\mathrm{~b}=0.03$ \\
& $\mathrm{RL}=0.28(\mathrm{RL}=1 / 1+\mathrm{bCo})$ & \\
& $\mathrm{n}=1.37$ \\
Freundlich & $\mathrm{KF}=3.15$ & 0.9425 \\
&
\end{tabular}

\section{CONCLUSIONS}

The evaluations of a new treatment mode for removal of mercury ions from aqueous solutions have been examined. In this work, Aspergillus Sp. used as an effective biosorbent and modified by 1,10-phenanthroline, the characterization of FTIR spectra and SEM analyses confirmed the macro groups grafted successfully on the surface of Aspergillus Sp. Nevertheless, solution $\mathrm{pH}$ had obvious influences on the biosorption capacity of $\mathrm{Hg} 2+$ ions and it was found that the biosorption capacity $(39.8 \mathrm{mg} / \mathrm{g})$ and biosorption efficiency $(\mathrm{R} \%=89)$ at $\mathrm{pH}$ equal to 3 . In turn, the maximum adsorption efficiency of mercury onto modified Aspergillus Sp. was found decrease with rise of temperature due to the fact that the adsorption is an exothermic in nature.

Furthermore, the experimental investigations were performed used most recommended isotherm (Hill, Sips, Langmuir and Freundlich) models in order to control the biosorption capacity, among these applicable models the Hill $(\mathrm{R} 2=0.9896)$ and $\operatorname{Sips}(\mathrm{R} 2=0.9863)$ models fitted well enough with experimental data followed by Langmuir(R2= 0.9715). Thus, the equilibrium data almost fitted to the Freundlich isotherm supporting the postulation of heterogeneous shape of biosorption to certain range.

\section{REFERENCES}

Adams, J., Aggarwal, M. M., Ahammed, Z., Amonett, J., Anderson, B. D., Arkhipkin, D., . . . A.N.Zubarev, A. N. (2005). Experimental and theoretical challenges in the search for the quark-gluon plasma: The STAR Collaboration's critical assessment of the evidence from RHIC collisions. Nuclear Physics A, 757(1-2), 102-183. doi:10.1016/j.nuclphysa.2005.03.085

Adie, D. B., Olarinoye, N. O., Oke, I. A., Ismail, A., Lukman, S., \& Otun, J. A. (2010). Removal of lead ions from aqueous solutions using powdered corn cobs. The Canadian Journal of Chemical Engineering, 88(2), 241-255. doi:10.1002/cjce. 20264

Ahalya, N., Ramachandra, T. V., \& Kanamadi, R. D. (2003). Biosorption of heavy metals. Research journal of chemistry and enviroment, 7(4), 71-79.

Ajayi, O. O., Oladipo, M. O., Ogunsuyi, H. O., \& Adebayo, A. O. (2002). Determination of the minor and trace elements in Biriniwa's tin pyrite and ornamental lead/zinc ore using neutron activation analysis. Bulletin of the Chemical Society of Ethiopia, 16(2), 207-212.

$/ 188$ https://www.ajol.info/index.php/bcse/article/view/20944 56

Aubert, B., Barate, R., Boutigny, D., Couderc, F., Karyotakis, Y., Lees, J. P., . . Stugu, B. (2005). Observation of a broad structure in the $\pi+\pi-\mathrm{J} / \psi$ mass spectrum around 4.26 GeV/c 2. Physical review letters, 95(14), 142001.
doi:10.1103/PhysRevLett.95.142001

Brinza, L., Dring, M., \& Gavrilescu, M. (2007). Marine Micro and Macro Algal Species as Biosorbents for Heavy Metals. Enviromental Engineering and Management Journal, 6, 237-251.

Chakraborty, S., Chowdhury, S., \& Saha, P. (2011). Adsorption of Crystal Violet from aqueous solution onto $\mathrm{NaOH}$-modified rice husk. Carbohydrate Polymers, 86(4), 1533-1541. doi:10.1016/j.carbpol.2011.06.058

Conesa, A., Götz, S., García-Gómez, J. M., Terol, J., Talón, M., \& Robles, M. (2005). Blast2GO: a universal tool for annotation, visualization and analysis in functional genomics research. Bioinformatics, 21(18), 3674-3676. doi:10.1093/bioinformatics/bti610

Debnath, S., \& Ghosh, U. C. (2008). Kinetics, isotherm and thermodynamics for $\mathrm{Cr}$ (III) and $\mathrm{Cr}$ (VI) adsorption from aqueous solutions by crystalline hydrous titanium oxide. Journal of Chemical Thermodynamics, 40(1), 67-77. doi:10.1016/j.jct.2007.05.014

Elifantz, H., \& Tel-Or, E. (2002). Heavy Metal Biosorption by Plant Biomass of the Macrophyte Ludwigia Stolonifera. Water, Air, and Soil Pollution, 141(1-4), 207-218. doi:https://doi.org/10.1023/A:1021343804220

Foo, K. Y., \& Hameed, B. H. (2010). Insights into Modeling of Adsorption Isotherm Systems. The Chemical Engineering Journal, 156(1), 2-10. doi:10.1016/j.cej.2009.09.013

Gaad, G. M. (1990). Fungi and yeasts for metal binding. In H. L. Ehrlich, \& C. L. Brierley, Microbial Mineral Recovery (pp. 249-275). New York: McGraw-Hill.

Gladstone, R. A., Jefferies, J. M., Tocheva, A. S., Beard, K. R., Garley, D., Chong, W. W., . . Clarke, S. C. (2015). Five winters of pneumococcal serotype replacement in UK carriage following PCV introduction. Vaccine, 33(17), 2015-2021. doi: 10.1016/j.vaccine. 2015.03 .012

Kar, P., \& Misra, M. (2004, September). Use of keratin fiber for separation of heavy metals from water. Journal of Chemical Technology and Biotechnology, 79(11), 1313-1319. doi:10.1002/jctb.1132

Ledin, M., Krantz-Rulcker, C., \& Allard, B. (1996). ZN, CD AND HG ACCUMULATION BY MICROORGANISMS, ORGANIC AND INORGANIC SOIL COMPONENTS IN MULTICOMPARTMENT SYSTEMS. SOIL BIOLOGY AND BIOCHEMISTRY, 28(6), 791-799.

Liu, J., Mazumdar, D., \& Lu, Y. (2006). A Simple and Sensitive "Dipstick" Test in Serum Based on Lateral Flow Separation of Aptamer-Linked Nanostructures. Angewandte Chemie, 118(47), 8123-8127.

Marshall, W. E., Wartelle, L. H., Boler, D. E., Johns, M. M., \& Toles, C. A. (1999). Enhanced metal adsorption by soybean hulls modified with citric acid. Bioresource Technology, 69(3), 263-268. doi:https://doi.org/10.1016/S0960-8524(98)001850

Mittal, A., Damodar, J., \& Mittal, J. (2013). Adsorption of hazardous dye Eosin Yellow from aqueous solution onto waste material Deoiled Soya: Isotherm, kinetics and bulk removal. Journal of Molecular Liquids(179), 133-140. doi: 10.1016/j.molliq.2012.11.032

Nagamani, A., Kunwar, I. K., \& Manoharachary, C. (2006). Handbook of Soil Fungi . I K International Publishing House.

Nowicki, P., Kuszyńska, I., Przepiórski, J., \& Pietrzak, R. (2013). The effect of chemical activation method on properties of activated carbons obtained from pine cones. Central European Journal of Chemistry, 11(1), 78-85. doi:10.2478/s11532-0120140-0 
Oke, I. A., Olarinoye, N. O., \& Adewusi, S. R. (2008). Adsorption kinetics for arsenic removal from aqueous solutions by untreated powdered eggshell. Adsorption, 14(1), 73-83. doi:10.1007/s10450-007-9047-z

Okieimen, F. E., Ogbeifun, D. E., Nwala, G. N., \& Kumsah, C. A. (1985). Binding of cadmium, copper, and 5 lead ions by modified cellulosic materials. Bulletin of Environmental Contamination and Toxicology, 34(1), 866-870.

Patil, A. K., \& Shrivastava, V. S. (2010). Alternanthera bettzichiana Plant powder as Low Cost. International Journal of ChemTech Research, 2(2), 842-850.

Pavlish, J. H., Holmes, M. J., Benson, S. A., Crocker, C. R., \& Galbreath, K. C. (2004). Application of sorbents for mercury control for utilities burning lignite coal. Fuel Processing Technology, 85(6-7), 563-576. doi:https://doi.org/10.1016/j.fuproc.2003.11.022

Rangsayator, N., Upatham, E. S., Kruatrachue, M., Pokethitiyook, P., \& Lanza, G. (2002). Phytoremediation potential of Spirulina (Arthrospira) platensis: biosorption and toxicity studies of cadmium. Enviromental Pollution, 119(1), 45$53 . \quad$ Retrieved from https://www.ncbi.nlm.nih.gov/pubmed/12125728

Ranjbar, M., Malakooti, E., \& Sheshmani, S. (2013). Synthesis and Characterization of Mercury(II) Complexes Containing 2,9-Dimethyl-1,10-phenanthroline by Sonochemical Method. Journal of Chemistry. doi:http://dx.doi.org/10.1155/2013/560983

Rashid, B. Z., Omer, R. A., \& Salih, S. J. (2016). Characterization and Antimicrobial Efficiency of Silver Nanoparticles Based Reduction Method. International Journal of
Current Microbiology and Applied Sciences, 5(8), 802-810. doi:10.20546/ijcmas.2016.508.089

Salih, S. J. (2014). Removal of Basic Dyes from Aqueous Solution by Chloroacetic Acid Modified Ferula Communis Based Adsorbent: Thermodynamic and Kinetic Studies. Koya University, 1-72.

Salih, S. J., \& Rashid, B. Z. (2015). Cranberry Stem as an Efficient Adsorbent and Eco-Friendly for Removal of Toxic Dyes from Industrial Wastewater. International Journal of Pharmaceutical Chemistry, 5(6), 207-217. doi:10.7439/ijpc.v5i6.2039

Salih, S. J., \& Samil, A. K. (2016). Synthesis, characterization and evaluation of antibacterial efficacy of 1 zinc oxide nanoparticles. Pharmaceutical and Biological Evaluations, 3(3), 327-333.

Shukla, S. R., \& Pai, R. S. (2005). Adsorption of Cu(II), Ni(II) and Zn(II) on modified jute fibres. Bioresource Technology, 96(13), 1430-1438. doi: 10.1016/j.biortech.2004.12.010

Tokcaer, E., \& Yetis, U. (2006). Pb(II) biosorption using anaerobically digested sludge. Journal of Hazardous Materials, 137(3), 1674-1680. doi:10.1016/j.jhazmat.2006.05.004

Venkatesh, V., Morris, M. G., Davis, G. B., \& Davis, F. D. (2003). User Acceptance of Information Technology: Toward a Unified View. MIS Quarterly, 27(3), 425-478. Retrieved from http://www.jstor.org/stable/30036540

Zhang, W., Li, H., Kan, X., Dong, L., Yan, H., Jiang, Z., . . Cheng, R. (2012). Adsorption of anionic dyes from aqueous solutions using chemically modified straw. Bioresource Technology, 117, 40-47. doi:10.1016/j.biortech.2012.04.064 